\title{
The analysis of spring potency for domestic uses (Case study: Wanadadi Sub-district, Banjarnegara-Indonesia)
}

\author{
Gita Oktaviani Fadilah ${ }^{1}$ dan Margaretha Widyastuti ${ }^{1 *}$ \\ ${ }^{1}$ Department of Environmental Geography, Faculty of Geography, Universitas Gadjah Mada, 55281 Yogyakarta, \\ Indonesia
}

\begin{abstract}
Water is a fundamental human need, and one of the sources constantly available in rainy and dry seasons is spring. The residents of Wanadadi Sub-district (Banjarnegara, Indonesia) rely on spring water as an alternative source, specifically to deal with water scarcity in dry seasons. This research was intended to investigate the potential of the springs based on their availability and quality to meet domestic water requirements. There has never been a study focusing on the springs in the sub-district; therefore, the results can give an overview of their potential and suitable conservation strategies. This research also enriches scientific knowledge of spring characteristics in structural depressions and hill slopes. Spring availability was determined by measuring the discharge of 34 springs and comparing the results with the total water needs. Spring water quality was identified by testing the water samples of eleven springs, each representing a village in the sub-district, and comparing the parameter values with the standards for sanitation and hygiene purposes issued in the Decree of the Minister of Health No. 32/2017. The results showed that based on water availability the springs in five villages have good potential. Meanwhile, in terms of quality the springs in all villages have very low potential.
\end{abstract}

Keywords: spring discharge, spring water quality, the potential of springs, Wanadadi Sub-district

\section{Introduction}

Water is one of the essential substances on earth used to meet diverse fundamental human needs in, among others, the domestic sector, fisheries, agricultural practices, and transportation. Its quantity and quality determine to what extent a source can fulfill the population's demands. Water volume and discharge indicate the amount of water available for this purpose. Meanwhile, quality restricts the intended use of a water source and is generally estimated by evaluating the physical, chemical and biological properties as manifestations of natural conditions and anthropogenic interferences that can affect human and aquatic system health [1].

Water can be extracted from various sources, such as groundwater, rivers, lakes, and precipitation. Springs are also among the water sources available and thus widely used in rainy and dry seasons [2]. Springs are the emergence of subterranean water that is concentrated at the surface of the ground in a perceptible current and are distinguished from seepage [3]. The emergence can be caused by gravitational and non-gravitational forces. Gravity springs include depression springs, contact springs, artesian springs, springs in impervious rocks and solution tubular/cavern springs [4]. Springs usually appear on volcanic slopes (particularly at slope breaks), in specific geological structures like fractures and faults and in karst areas.

The annual increase in population size inevitably raises total water requirements and risks of water scarcity issues. There are frequent reports of shortages in the domestic sector of Wanadadi Sub-district, especially during the dry season when water levels in household and communal wells are lower. To deal with this, the residents extract water from springs as an alternative to the dried wells. For this reason, the research sought to identify the potential of springs in the sub-district to meet local demands in terms of quantity (availability) and quality. The spring water availability was determined by comparing the measured discharges with the total water needs calculated according to the provisions set by the National Standardization Body of Indonesia in SNI 196728.1-2002. As for quality, it was examined by comparing the parameter values measured in the field and the laboratory with the water quality standards for sanitation and hygiene purposes issued in the Decree of the Minister of Health No. 32 of 2017.

Research on the potential availability and quality of water from these springs is new and has never been conducted in Wanadadi Sub-district. The current

\footnotetext{
*Corresponding author: mwiwik@ugm.ac.id
} 
research can provide an overview to the community and government authorities regarding the potential of springs and a reference to regulate spring water utilisation and formulate spring conservation strategies. It also enriches scientific information about spring characteristics (i.e., water availability and quality) in structural hill slopes and depressions.

\section{Research Location}

Wanadadi is a sub-district in the Banjarnegara District area. Astronomically, it is located at 343722-353804 $\mathrm{mE}$ and 9181607-9189774 $\mathrm{mN}$. It administratively consists of eleven villages: Tapen, Kasilib, Karangjambe, Wanadadi, Wanakarsa,
Karangkemiri, Gumingsir, Linggasari, Medayu, Kandangwangi and Lemahjaya. Geologically, the subdistrict lies on three geological formations: alluvium (Qa), terrace deposits (Qt) and the breccia of the Ligung Formation (QTbi) (Fig. 1).

Based on the hydrological condition of the groundwater itself, the sub-district is part of the discharge area of the Purwokerto-Purbalingga Groundwater Basin. It is composed of three hydrogeological units: alluvial deposits, terrace deposits and old volcanic complexes in the form of volcanic breccias and agglomerates [5]. Meanwhile, according to the Schmidt-Fergusson classification the sub-district has a C climate or wet climate.

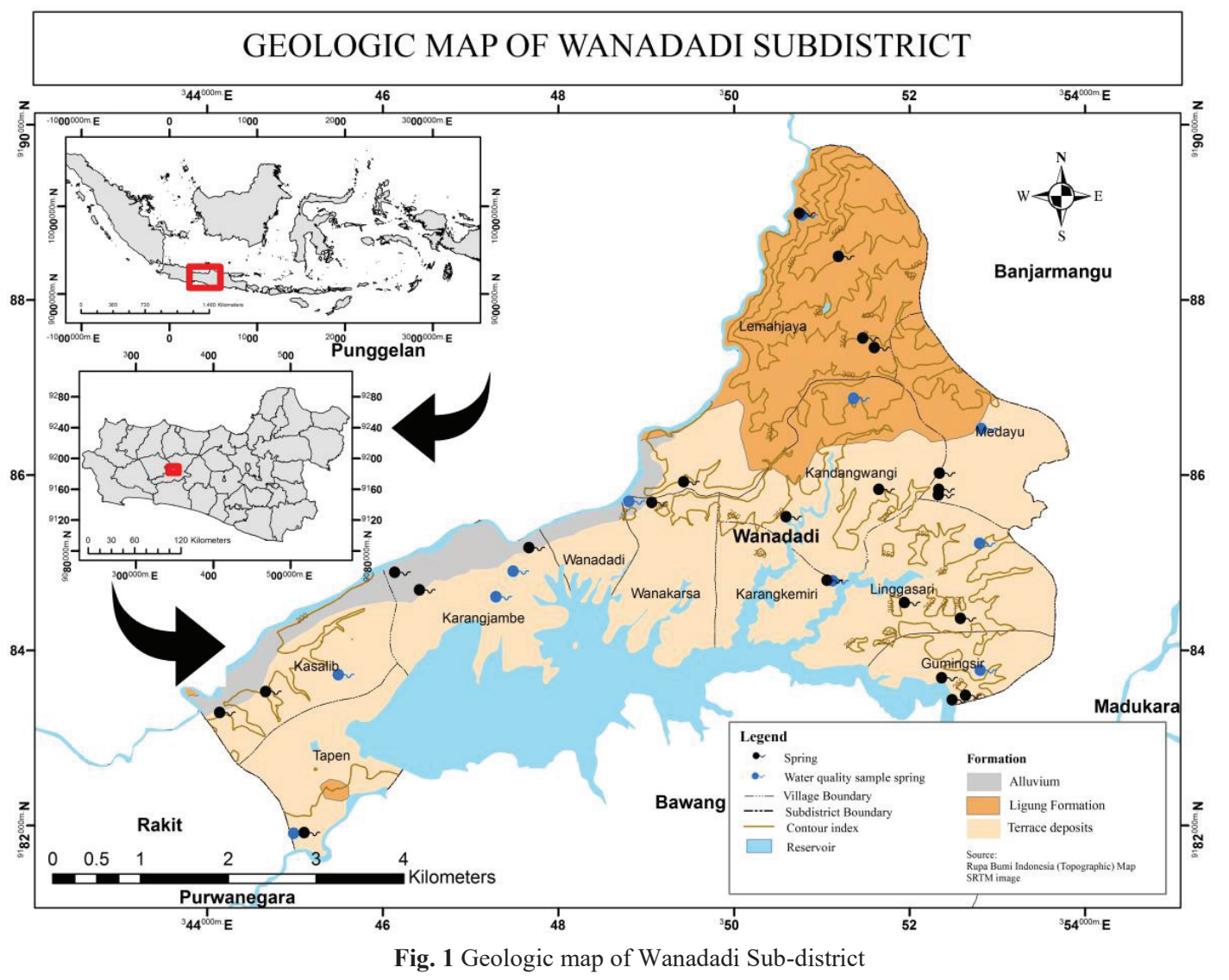

\section{Method}

The spatial distribution and discharge of the 34 springs in the Wanadadi Sub-district were observed directly in the field. Spring discharge was measured in the dry season to determine the lowest amount of water available to meet the local domestic requirements. Because the springs appear as concentrated outflows (like water coming out of a faucet), volumetric gauging is suitable for measuring their discharges. In this method flow rate or discharge, $Q\left(\mathrm{~m}^{3} / \mathrm{s}\right)$, is the volume of water filling a measuring glass, $V\left(\mathrm{~m}^{3}\right)$, per unit of time, $t(\mathrm{~s})$, or as presented in Eq. 1 below [6].

$$
\mathrm{Q}=\mathrm{V} / \mathrm{t}
$$

In this context flow rates indicate the quantity of water released by a spring. These data were further categorised into eight classes of potential according to Meinzer [4], from I (largest) to VIII (smallest). The total discharge (availability) of all springs in one unit of analysis, i.e., village, was calculated to obtain water availability in one year. This figure was then compared with the domestic water consumption of the population of each village, which is different between urban and rural areas. Because the sub-district shows the characteristics of a rural region, the consumption was assumed to be $60 \mathrm{~L} /$ day/person. The annual domestic water requirement, $Q D M I$, is the number of days in one year (365 days) times population size and $60 \mathrm{~L}$, or 
as shown in Eq. 2 below [7]. Here, population size is the number of people living in one unit of analysis.

$\mathrm{Q}(\mathrm{DMI})=365$ days $\times \Sigma$ population $\times 60 \mathrm{~L}$

The springs are assumed to release a fixed amount of water (availability) from 2020 until 2030, while the water requirement is assumed to increase with population growth. The population data in the next ten years were obtained using the geometric population projection. This method is widely applied because it is easy to use, and the projected data are considered close to the actual condition [8]. It assumes that the population growth rate in each year does not change [9]. The geometric growth was calculated using Eq. 3 below [9]:

$$
P n=P o(1+r)^{n}
$$

where $P n$ is the population after $n$ years, $P o$ is the population at time zero, $r$ is the rate of growth and $n$ is time in years.

Here, population projection was used to calculate the amount of domestic water required in the projected year. This figure was compared with the fixed amount of water released from springs (availability) throughout the years of observation to determine the potential of springs as a domestic water supply, assuming they are the only water source used in each village. This procedure enabled the calculation of the annual water balance between water availability and requirements for domestic use in 2020 (at the time of the discharge measurement) and 2030 (projected water availability).

For the water quality analysis, samples were collected from eleven springs, each representing the village of Wanadadi. Some data were tested directly in the field, namely taste, odour, temperature, TDS and
$\mathrm{pH}$. Meanwhile, some others were analysed in the laboratory: chemical properties other than $\mathrm{pH}$ and biological properties, i.e., total coliforms. In the study area the springs emerge through one or several openings on the ground surface and are accumulated and stored in a tank or container. Therefore, samples were collected from the tap into the sample bottle and preserved for further analysis in the laboratory.

All water quality data were analysed and presented in maps to illustrate the distribution of springs along with their physical, chemical and biological properties. To identify the springs' potential, each parameter value of these properties was also compared with their respective allowable levels in water used for sanitation and hygiene purposes, as described in the water quality standards in the Decree of the Minister of Health No. 32 of 2017.

\section{Results and discussion}

The results of the discharge measurements at 34 springs and the water quality tests at 11 selected springs demonstrate the potential of these water sources to meet the basic household needs in Wanadadi Sub-district.

\subsection{Spring discharge}

The springs in Wanadadi have a vital part in fulfiling the local domestic water needs. Their discharge indicates to what extent they can play this role. To meet the increasing water demand, spring water availability must be identified to create a basis for planning and conserving water sources in the future.

Table 1. The spring discharges of Wanadadi Sub-district and their Meinzer's classification

\begin{tabular}{|c|c|c|c|c|c|c|c|}
\hline Villages & Springs & $\begin{array}{c}\text { Discharge } \\
(\mathrm{L} / \mathrm{s})\end{array}$ & $\begin{array}{l}\text { Meinzer's } \\
\text { Classification }\end{array}$ & Villages & Springs & $\begin{array}{c}\text { Discharge } \\
(\mathrm{L} / \mathrm{s})\end{array}$ & $\begin{array}{c}\text { Meinzer's } \\
\text { Classification }\end{array}$ \\
\hline \multirow[t]{2}{*}{ Tapen } & Tapen 1 & $\begin{array}{c}\text { Not } \\
\text { measurable }\end{array}$ & - & \multirow[t]{3}{*}{ Kandangwangi } & Kandangwangi 1 & 0.01 & VII \\
\hline & Tapen 2 & 0.18 & VI & & Kandangwangi 2 & 0.02 & VII \\
\hline \multirow[t]{3}{*}{ Kasilib } & Kasilib & 0.10 & VI & & Wanatawang & 0.11 & VI \\
\hline & Kasilib 2 & $\begin{array}{c}\text { Not } \\
\text { measurable }\end{array}$ & - & \multirow[t]{2}{*}{ Karangkemiri } & Karangkemiri 1 & 0.18 & VI \\
\hline & Karangpucung & 0.05 & VII & & Karangkemiri 2 & 0.22 & VI \\
\hline \multirow[t]{3}{*}{ Karangjambe } & Karangjambe 1 & 0.14 & VI & \multirow[t]{4}{*}{ Medayu } & Medayu 1 & $\begin{array}{c}\text { Not } \\
\text { measurable }\end{array}$ & - \\
\hline & Karangjambe 2 & 0.69 & VI & & Medayu 2 & 0.08 & VII \\
\hline & Bangkong & 0.58 & VI & & Medayu 3 & 0.14 & VI \\
\hline \multirow[t]{2}{*}{ Wanadadi } & Punthukrandu & 0.64 & VI & & Medayu 4 & 0.04 & VII \\
\hline & Gandu & $\begin{array}{c}\text { Not } \\
\text { measurable }\end{array}$ & - & \multirow[t]{3}{*}{ Linggasari } & Linggasari 1 & 0.21 & VI \\
\hline \multirow[t]{2}{*}{ Wanakarsa } & Wanakarsa 1 & $\begin{array}{c}\text { Not } \\
\text { measurable }\end{array}$ & - & & Linggasari 2 & 0.36 & VI \\
\hline & Wanakarsa 2 & 0.18 & VI & & Linggasari 3 & 0.01 & VII \\
\hline \multirow[t]{6}{*}{ Lemahjaya } & Lemahjaya 1 & $\begin{array}{c}\text { Not } \\
\text { measurable }\end{array}$ & - & \multirow[t]{6}{*}{ Gumingsir } & Gumingsir 1 & $\begin{array}{c}\text { Not } \\
\text { measurable }\end{array}$ & - \\
\hline & Tampingan 1 & 0.20 & VI & & Gumingsir 2 & 0.10 & VII \\
\hline & Tampingan 2 & 0.13 & VI & & Gumingsir 3 & 0.03 & VII \\
\hline & Karabaok 1 & $\begin{array}{c}\text { Not } \\
\text { measurable }\end{array}$ & - & & Gumingsir 4 & 0.04 & VII \\
\hline & Karabaok 2 & $\begin{array}{c}\text { Not } \\
\text { measurable }\end{array}$ & - & & & & \\
\hline & Karabaok 3 & 0.73 & VI & & & & \\
\hline
\end{tabular}


According to the discharge classification by Meinzer [4], the 34 springs observed fell into different classes. Nearly half of them (16) were categorised into class VI $(0.1-1 \mathrm{~L} / \mathrm{s})$, nine were class VII $(0.01-0.1 \mathrm{~L} / \mathrm{s})$, and the remaining nine springs were not gaugeable because they were covered with cement (Table 1). Based on classes VI and VII criteria, the springs in the sub-district were concluded as low-yielding. Several factors like geological structures, surface relief and climatic conditions are responsible for the small discharge [10]. The springs in Wanadadi are formed when the topography intersects relatively shallow water tables; thus, the amount of water released from the springs is not significant. Also, the slope where the springs emerge is fairly steep, and their discharges were measured in dry months (August-September) where there is normally a decline in groundwater recharge (seasonal factor). Therefore, despite the small discharge, all springs have been classified as perennial flows.Specific geological structures like faults and fractures are known factors of spring discharge [11]. However, because these geological structures are not found in the study area, their influence is negligible. Also, different rock constituents of aquifers (i.e., the Ligung Formation, terrace deposits and alluvium formation) do not lead to substantial variation in spring discharges. This is evident from the discharge classification results, which vary between mere two classes: VI and VII.

\subsection{Spring water quality}

Quality determines the suitability of spring water for domestic use. Here, the parameters observed were of physical properties: taste, odour, temperature and TDS and chemical properties: nitrate $\left(\mathrm{NO}_{3}-\mathrm{N}\right)$, nitrite $\left(\mathrm{NO}_{2}-\mathrm{N}\right)$, sulfate $\left(\mathrm{SO}_{4}\right)$ and $\mathrm{pH}$. The water quality of each spring is presented in the map in Fig. 2.

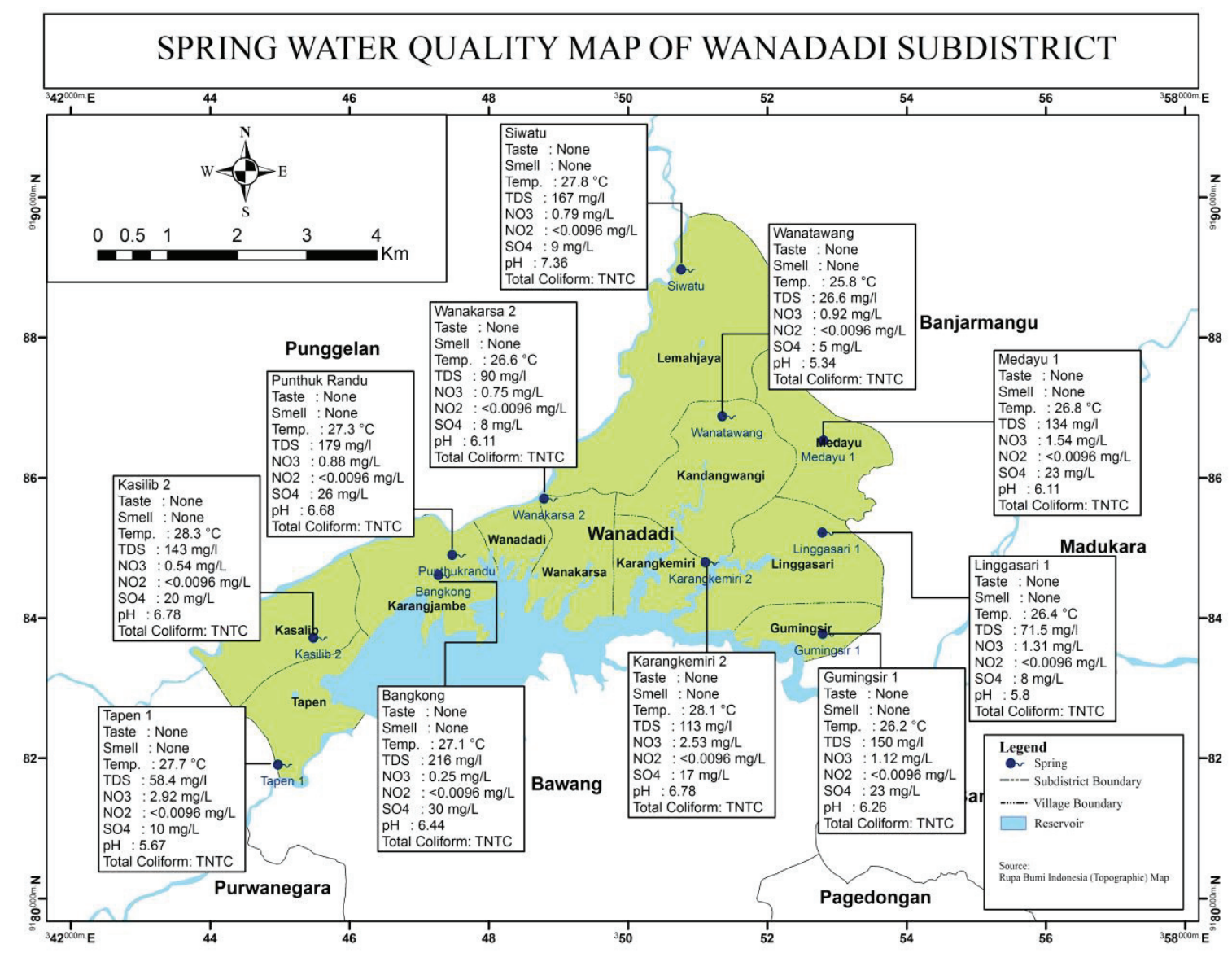

Fig. 2 The water quality map of the eleven sampled springs in Wanadadi Sub-district

Direct measurements in the field revealed that the water at eleven sampled springs was physically tasteless and odourless, with no specific indication of any harmful substances. The measured spring temperature was in the range of $25.8-28.3^{\circ} \mathrm{C}$. The air temperature average of the Banjarnegara District in 2020 was $24.33^{\circ} \mathrm{C}[12]$. At some selected springs, the temperatures deviated less than $3^{\circ} \mathrm{C}$, or within the acceptable range for sanitation and hygiene purposes.
Any temperature exceeding the upper limit indicates the presence of dissolved chemicals in large quantities or organic matter decomposition, thus making a body of water unsuitable for consumption [13].

TDS (total dissolved solids) intercorrelates with other water quality parameters: turbidity, hardness, alkalinity and conductivity [14]. The lowest TDS, 26.6 $\mathrm{mg} / \mathrm{L}$, was identified at Wanatawang Spring (Kandangwangi Village), whereas the highest, 216 
$\mathrm{mg} / \mathrm{L}$, was at Bangkong Spring (Karangjambe Village). With this range of TDS, all samples met the water quality standard for sanitation and hygiene, i.e., below $1000 \mathrm{mg} / \mathrm{L}$. A particularly high TDS can make water taste bitter and increase hardness and corrosivity; both are signs of decreased water quality [14].

Nitrates found in water sources are usually attributable to chemical contamination from residues of urea in fertiliser [15] and are sensitive to the entry of waste generated by livestock and crop farming [16]. Contamination of a source of water by nitrates $\left(\mathrm{NO}_{3}{ }^{-} \mathrm{N}\right)$ and nitrites $\left(\mathrm{NO}_{2}{ }^{-} \mathrm{N}\right)$ is of great concern due to their detrimental impacts on health [16]. Even in small doses, excess nitrate can cause mild illnesses, such as goiter. If present in lethal doses, both compounds can cause methemoglobinemia, i.e., the conversion of more than $10 \%$ hemoglobin to methemoglobin, resulting in dysrhythmias, heart attack, coma and death [17]. The nitrate contents $\left(\mathrm{NO}_{3}{ }^{-} \mathrm{N}\right)$ of the spring water samples did not exceed their maximum allowable presence in water for sanitation and hygiene purposes, $<0.0096$ $\mathrm{mg} / \mathrm{L}$.

Sulphate $\left(\mathrm{SO}_{4}\right)$ in groundwater is mainly derived from sulphate mineral deposits in the rock constituents of an aquifer, although in some cases industrial waste has been identified as a source of excess sulphates [18]. Drinking water containing this compound tastes bitter with a metallic aftertaste and has laxative effects [19]. The laboratory analysis results showed sulphate contents varying from $5 \mathrm{mg} / \mathrm{L}$ to $30 \mathrm{mg} / \mathrm{L}$, which are far below its upper limit value, $400 \mathrm{mg} / \mathrm{L}$.

$\mathrm{pH}$ measures the intensity of the acidity or alkalinity of a dilute liquid and represents its hydrogen ion concentration [20]. The $\mathrm{pH}$ values of the 11 springs ranged from 5.34 to 7.36. Most of the samples had acidic $\mathrm{pH}$ of lower than 6.5 , which can increase metal object corrosivity, give water an unpleasant taste, induce the toxicity of several chemicals and disrupt health [20].

Total coliform is a measure of biological water quality. The test used the standard membrane filter/plate count procedure number 9222 by the American Public Health Association (AHPA), and all samples showed TNTC results (too numerous to count), meaning that the total bacterial colonies per membrane filter at the time of testing were above 200 colonyforming units (CFU) per $100 \mathrm{ml}$ [21]. It also indicates that the number of colonies has exceeded the upper limit allowed for each plate to produce a reliable calculation and does not match the actual count. Coliform bacteria in a water source can cause various diseases, such as diarrhea and nausea [20].

\subsection{Spring potential}

\subsubsection{Water balance}

Water balance demonstrates the potential of springs to fulfil domestic water needs in terms of availability or quantity. Table 2 summarises the results of the water balance calculation for each village. The total annual discharge was measured directly at most of the sampled springs. Only a few were not gaugeable because the spring water collection chambers were closed; therefore, their discharge was estimated from pumping capacity. For instance, Tapen 1 and Kasilib 2 Springs have been widely used by the communities in Tapen and Kailib Villages and installed with a jet pump with a capacity of $75 \mathrm{~L} /$ minute. Other examples include Medayu 1 and Gumingsir 1 Springs, whose water can be extracted with the available shallow groundwater pumps at a capacity of $33 \mathrm{~L} /$ minute.

Table 2. The water balance of springs in Wanadadi Sub-district in 2020 and 2030

\begin{tabular}{lrrrlrrrr} 
Years & \multicolumn{9}{c}{$\mathbf{2 0 2 0}$} & \multicolumn{3}{c}{$\mathbf{2 0 3 0}$} \\
\hline Villages & $\begin{array}{c}\text { Spring } \\
\text { discharge } \\
\left(\mathrm{m}^{3} / \text { year }\right)\end{array}$ & $\begin{array}{c}\text { Water } \\
\text { requirements } \\
\left(\mathrm{m}^{3} / \text { year }\right)\end{array}$ & $\begin{array}{l}\text { Water } \\
\text { balance } \\
\left(\mathrm{m}^{3} / \text { year }\right)\end{array}$ & Notes & $\begin{array}{c}\text { Spring } \\
\text { discharge } \\
\left(\mathrm{m}^{3} / \text { year }\right)\end{array}$ & $\begin{array}{c}\text { Water } \\
\text { requirements } \\
\left(\mathrm{m}^{3} / \text { year }\right)\end{array}$ & $\begin{array}{c}\text { Water } \\
\text { balance } \\
\left(\mathrm{m}^{3} / \text { year }\right)\end{array}$ & Notes \\
\hline Tapen & 84564.58 & 49400.91 & 35163.67 & Surplus & 84564.58 & 50442.57 & 34122.01 & Surplus \\
\hline Kasilib & 83527.16 & 53795.54 & 29731.62 & Surplus & 83527.16 & 54929.86 & 28597.31 & Surplus \\
\hline Karangjambe & 44578.68 & 40832.49 & 3746.18 & Surplus & 44578.68 & 41693.48 & 2885.20 & Surplus \\
\hline Wanadadi & 20358.41 & 67796.51 & -47438.10 & Deficit & 20358.41 & 69226.05 & -48867.64 & Deficit \\
\hline Wanakarsa & 5765.04 & 60376.44 & -54611.40 & Deficit & 5765.04 & 61649.52 & -55884.48 & Deficit \\
\hline Lemahjaya & 33519.97 & 108717.34 & -75197.37 & Deficit & 33519.97 & 111009.72 & -77489.75 & Deficit \\
\hline Kandangwangi & 4529.78 & 67487.35 & -62957.56 & Deficit & 4529.78 & 68910.36 & -64380.58 & Deficit \\
\hline Karangkemiri & 12557.53 & 52890.11 & -40332.58 & Deficit & 12557.53 & 54005.34 & -41447.81 & Deficit \\
\hline Medayu & 164493.95 & 58035.58 & 106458.37 & Surplus & 164493.95 & 59259.30 & 105234.65 & Surplus \\
\hline Linggasari & 18146.90 & 52470.53 & -34323.63 & Deficit & 18146.90 & 53576.91 & -35430.01 & Deficit \\
\hline Gumingsir & 91877.97 & 33125.33 & 58752.63 & Surplus & 91877.97 & 33823.80 & 58054.16 & Surplus \\
\hline Total & 563919.98 & 644928.15 & -81008.16 & Deficit & 563919.98 & 658526.92 & -94606.93 & Deficit
\end{tabular}

Based on the calculated water balance in 2020 , five villages experienced a water surplus: Tapen, Kasilib, Karangjambe, Medayu and Gumingsir. Meanwhile, the springs with discharges lower than the domestic water requirements created a water deficit in six other villages, assuming that the residents only used water sourced from the local springs for their daily activities.
Even with the same spring discharge in the first and last years of observation, the projected water balance for 2030 showed an identical pattern: a water surplus in five villages. It can be concluded that the springs in these five villages have a good potential in terms of quantity and will be able to meet the domestic water 
needs of their residents in the future, at least for the next ten years

\subsubsection{Suitability with the water quality standards}

To assess the suitability of the spring water for sanitation and hygiene purposes, the research referred to the water quality standards issued in the Decree of the Minister of Health No. 32 of 2017. Samples of spring water were tested for taste, odour, temperature,

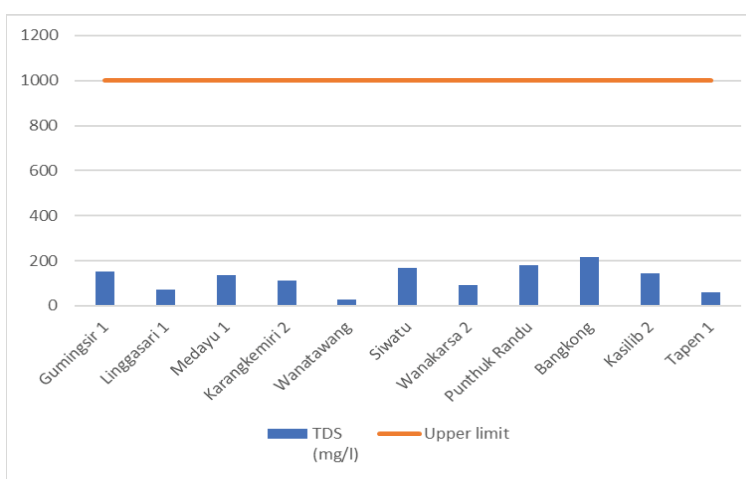

(a)

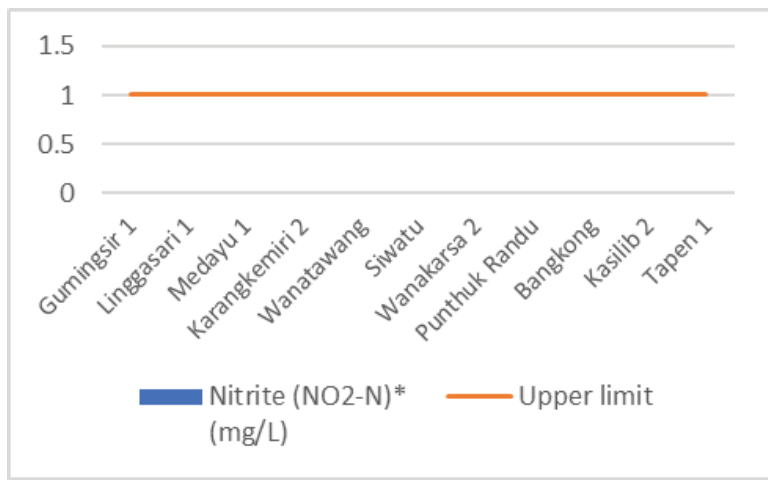

(c)

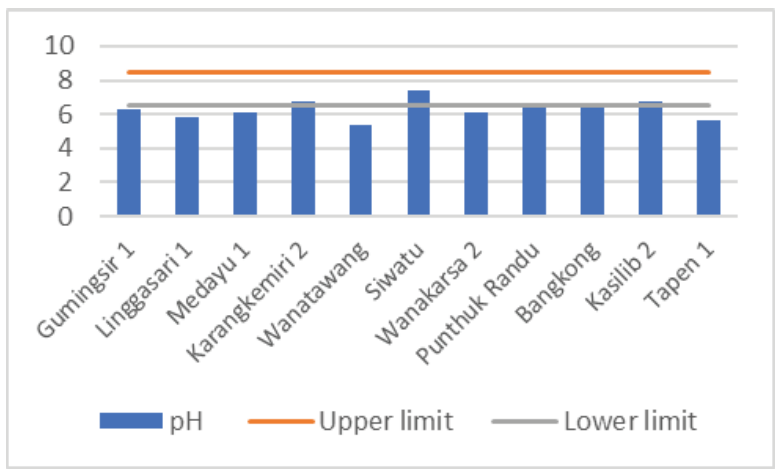

(e)
TDS, nitrite, nitrate, $\mathrm{pH}$, sulphate and total coliform. Upon comparing the test results with the said standards, it was found that the eleven springs selected to represent each village had poor potential in terms of quality (Fig. 3). The taste, odour, TDS, nitrite, nitrate and sulphate were within the standards, but the temperature, $\mathrm{pH}$ and total coliform of several samples were either higher or lower than their allowable presence.

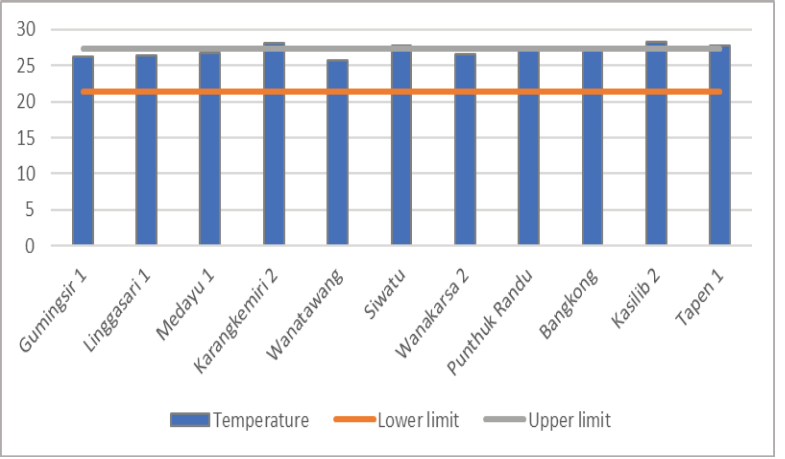

(b)

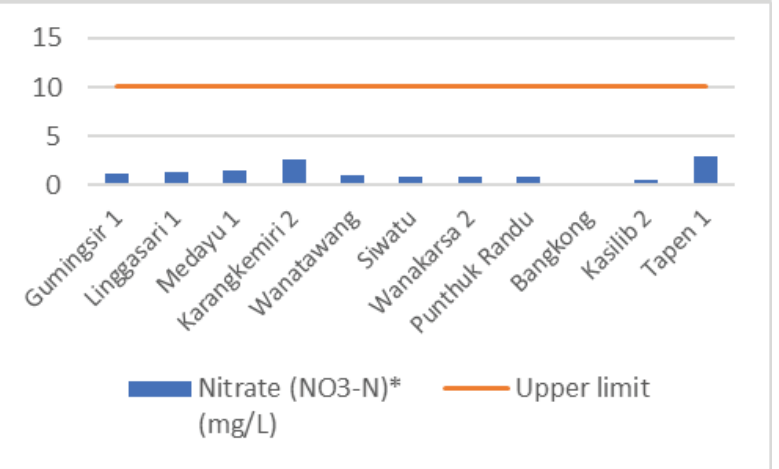

(d)

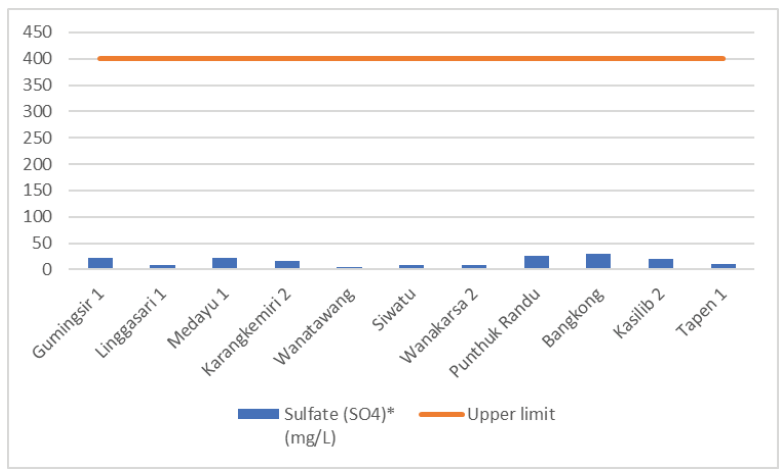

(f)

Fig. 3. Charts of the water quality test results and standards for sanitation and hygiene purposes: (a) TDS, (b) temperature, (c) nitrite content, (d) nitrate content, (e) $\mathrm{pH}$ and (f) sulphate

Total coliforms were found to be particularly high in all samples, as evident from the TNTC results in the microbial enumeration test. TNTC, or too numerous to count, means that the number of colonies observed is above $200 \mathrm{CFU} / 100 \mathrm{ml}$, exceeding the upper limit for water used in sanitation and hygiene activities, 50 CFU/100 ml. Most of the springs sampled for water quality testing are left uncovered and exposed to the surrounding elements, except for Medayu 1, Tapen 1 and Kasilib 2 Springs. Without cover structures and proper management, a water source is at high risk of contamination by the waste by-products of domestic activities, livestock farming and crop farming. Research conducted in Kenya proves that livestock and 
wild animals can increase total coliform counts in unprotected drinking water sources [22]. Another influencing factor is soil; for example, high E. Coli counts in Babadan (Umbulharjo, Yogyakarta) are associated with alluvial soils composed of clay layers. Alluvial soils generally have high porosity but low percolation and permeability, which barely filter out $E$. coli bacteria that tend to move vertically in groundwater [23]. In the Wanadadi Sub-district, Wanakarsa 2 Spring is located in an alluvial deposit complex, while most of the other springs are in the terrace deposit formation and the breccia of the Ligung Formation.

Similarly, $\mathrm{pH}$ was also the parameter that did not meet the water quality standards for sanitation and hygiene at six springs. Gumingsir 1, Linggasari 1, Medayu 1, Wanatawang, Wanakarsa 2, Bangkong and Tapen 1 had slightly acidic water below the lower limit value, 6.5. Many scholars have found several water bodies with low $\mathrm{pH}$; for example, $85 \%$ of the volcanic springs in São Miguel, Azores, have pH 5-7 [24]. Acid spring water can result from geological conditions at and around the location; for example, groundwater in Massachusetts is naturally acidic because of soil and rock factors [25]. The springs sampled and analysed in the water quality testing were located in the Ligung Formation, terrace deposits and alluvial deposits composed of volcanic materials with intermediate acidity levels [26]. Also, low $\mathrm{pH}$ can indicate the influence of surrounding human activities on water bodies, such as residential areas, markets, plantations and waste disposal [27]. For instance, Cirebon coastal waters Indonesia have $\mathrm{pH}$ values from 6.06 to 6.36 due to high detergent levels $(0.01-0.02 \mathrm{mg} / \mathrm{L})$ in the rivers that feed into these waters [28]. In Wanadadi, some springs are close to the settlements: Gumingsir 1, Medayu 1, Wanakarsa 2 and Tapen 1. Linggasari 1 Spring is located near fish ponds, Bangkong is near rice fields and settlements, while Wanatawang is in the middle of a plantation. Anthropogenic activities in the vicinity can generate and introduce waste into the springs and affect their $\mathrm{pH}$.

Like $\mathrm{pH}$, the temperatures did not meet the water quality standards at several springs. The water temperatures at Karangkemiri 2, Kasilib 2, Siwatu and Tapen 1 deviated about $3-4^{\circ} \mathrm{C}$ from the air temperature, or higher than the upper limit value. However, this does not classify the springs in Wanadadi Sub-district as hot springs, which otherwise have substantially higher temperatures, e.g., $45-80^{\circ} \mathrm{C}$ at some hot springs in southern Thailand [29] and $41-99^{\circ} \mathrm{C}$ at some hot springs in western Malaysia [30]. The high temperatures measured at the springs in Wanadadi can be influenced by solar radiation at the measurement time.

\section{Conclusion}

The research in Wanadadi Sub-district has found that the springs in Medayu Village have the highest water availability (a total discharge of $164493.95 \mathrm{~m}^{3}$ ), while those in Kandangwangi Village have the lowest $\left(4529.78 \mathrm{~m}^{3}\right)$. In 2020 the residents in Lemahjaya Village had the highest water requirement (108717.34 $\mathrm{m}^{3}$ ), but those in Gumingsir Village had the lowest $\left(33125.33 \mathrm{~m}^{3}\right)$. Based on the water balance, the springs in five villages (Tapen, Kasilib, Karangjambe, Medayu and Gumingsir) have great potentials in that the amount of water released could fulfil the domestic water needs in 2020 . The water balance projection for 2030 also shows the same results even though the water needs of each village have increased. In terms of quality, all springs have one to three parameters that do not meet the standards for sanitation and hygiene purposes set in the Decree of the Minister of Health No. 32 of 2017. The parameters in questions are $\mathrm{pH}$ (as detected at Gumingsir 1, Linggasari 1, Medayu 1, Wanatawang, Wanakarsa 2, Bangkong and Tapen 1) and temperature (Karangkemiri 2, Kasilib 2, Siwatu and Tapen 1). As evident from the TNTC results (too numerous to count) in the microbial enumeration test, all samples contain excessively high total coliforms (above $200 \mathrm{CFU} / 100 \mathrm{ml}$ ). Based on the availability and quality aspects, it can be concluded that not all springs in each village have good potential to sufficiently provide water for domestic activities. However, villages with surplus water balance can improve the local springs' potentials with proper water quality treatments.

\section{Acknowledgement}

The authors would like to thank Universitas Gadjah Mada (UGM) for funding this research through the Final Project Recognition Grant scheme (Hibah Rekognisi Tugas Akhir, RTA) in 2021. Gratitude is also extended to the Faculty of Geography UGM for providing the opportunity to complete this research and disseminate the results through this article. These supports are invaluable to the preparation and completion of the research.

\section{References}

1. D. Chapman, Water Quality Assessments - A Guide to Use of Biota, Sediments and Water in Environmental Monitoring, Second Edi (F \& FN Spon, London, 1996)

2. Sudarmadji, D. Darmanto, M. Widyastuti, and S. Lestari, J. Mns. Dan Lingkung. 23, 102 (2016)

3. M. F. N. Said and Sudarmadji, J. Bumi Indones. 3, 1 (2014)

4. D. K. Todd and L. W. Mays, (2005)

5. A. M. . Meyerink, Serayu Val. Proj. 4, 25 (1980)

6. Badan Standardisasi Nasional, Standar Nasional Indonesia: Perencanaan Sistem Penyediaan Air Minum (Badan Standardisasi Nasional, 2012)

7. Badan Standardisasi Nasional, Standar Nasional Indonesia: Penyusunan Neraca Sumber Daya - Bagian 1: Sumber Daya Air Spasial (Indonesia, 2002)

8. Ditjen Cipta Karya DPU, Buku Panduan Pengembangan Air Minum (Jakarta Selatan, 


\section{7)}

9. Badan Pusat Statistik, Pedoman Penghitungan Proyeksi Penduduk Dan Angkatan Kerja (Jakarta, 2010)

10. Z. Michalczyk, S. Chmiel, S. Głowacki, J. Sposób, and B. Zielińska, Ecohydrol. Hydrobiol. 20, 599 (2020)

11. L. W. Santosa, Forum Geogr. 20, 68 (2006)

12. Badan Pusat Statistik Kabupaten Banjarnegara, Banjarnegara Dalam Angka (Badan Pusat Statistik Kabupaten Banjarnegara, Banjarnegara, 2021)

13. F. Majid, H. Santjoko, and Narto, Pasir, Zeolit Dan Arang Aktif Sebagai Media Filtrasi Untuk Menurunkan Kekeruhan, TDS Dan e-Coli Air Sungai Selokan Mataram Yogyakarta (Yogyakarta, 2019)

14. V. Kothari, S. Vij, S. K. Sharma, and N. Gupta, Environ. Sustain. Indic. 9, 100093 (2021)

15. Abdurrivai and S. N, J. Sulolipu Media Komun. Sivitas Akad. Dan Masy. 17, 1 (2017)

16. Y. Kawagoshi, Y. Suenaga, N. L. Chi, T. Hama, H. Ito, and L. Van Duc, Sci. Total Environ. 657, 146 (2019)

17. A. E. Manampiring, Karya Ilm. 1 (2009)

18. P. Das, K. Maya, and D. Padmalal, Geothermics 90, 101997 (2021)

19. G. Prasad, A. S. Reshma, and M. Vinodini Ramesh, Mater. Today Proc. (2021)

20. I. G. A. P. R. Yoga, N. P. W. Astuti, and N. N.
A. Sanjaya, Higiene 6, 53 (2017)

21. APHA, APHA Method 9222: Standard Methods for the Examination of Water and Wastewater (1992)

22. D. Trajano Gomes da Silva, J. Ebdon, J. Okotto-Okotto, F. Ade, O. Mito, P. Wanza, E. Kwoba, T. Mwangi, W. Yu, and J. A. Wright, Int. J. Hyg. Environ. Health 230, 113602 (2020)

23. E. Winata and E. Hartantyo, J. Fis. Indones. 17, 8 (2013)

24. P. Freire, C. Andrade, R. Coutinho, and J. V.

25. United States Environmental Protection Agency New England, Healthy Drinking Waters for Massachusetts (Massachussets, 2007)

26. J. A. E. Tjahjono, in Kolok. Direktorat Inventar. Sumber Daya Miner. DIM (Jakarta, 2002)

27. Sudarto, S. F. Retnowaty, Y. Fitri, and A. Suroso, J. Phot. 5, 63 (2015)

28. T. Susana, Indones. J. Urban Environ. Technol. 5, 33 (2009)

29. W. Ngansom, K. Pirarai, and H. Dürrast, Geothermics 85, 101746 (2020)

30. H. Baioumy, M. Nawawi, K. Wagner, and M. H. Arifin, J. Volcanol. Geotherm. Res. 290, 12 (2015) 